\title{
IDENTIFICAÇÃO MORFOLÓGICA DE LEVEDURAS ISOLADAS DE PACIENTES COM QUADRO CLÍNICO DE CANDIDÍASE VULVOVAGINAL
}

\author{
Jessica Tauany Andrade*1, Carla Daiane Ferreira de Sousa ${ }^{1}$, Anderson \\ Junior de Freitas ${ }^{1}$, Marcelo Gonzaga de Freitas Araújo², Jaqueline Maria \\ Siqueira Ferreira ${ }^{1}$
}

\begin{abstract}
1Laboratório de Microbiologia da Universidade Federal de São João Del-Rei, Divinópolis/MG 2 Laboratório de Farmacologia da Universidade Federal de São João Del-Rei, Divinópolis/MG *email: jessicatauany@gmail.com
\end{abstract}

\section{Resumo}

Candida albicans é a espécie de levedura mais importante encontrada no trato genital feminino, $75 \%$ das mulheres adultas tiveram episódios de candidíase vulvovaginal (CVV), com prevalência de C.albicans de 70 a 90\%. Tendo em vista a existência de relatos de resistência desta espécie a azóis e o fato da CVV poder ser causada por outras espécies, é importante a identificação correta da levedura para a seleção de um antifúngico para o tratamento eficaz. O objetivo deste trabalho foi realizar a identificação macro e micromorfológica de cinco leveduras isoladas de pacientes com quadro clínico de CVV. Para isso, foram feitos (i) Estudos das características macromorfológicas da levedura; (ii) Prova do tubo germinativo; (iii) Cultivo em lâmina para prova de formação de Clamidósporo e (iv) Testes bioquímicos. Os cinco isolados clínicos testados apresentaram como características macromorfológicas coloração branca ou creme, textura cremosa e superfície lisa em ágar Sabouraud dextrose, bem como formação de sedimento em caldo Sabouraud dextrose. Em relação às características micromorfológicas, foi verificada a formação de tubo germinativo após 3 horas de incubação a $37^{0} \mathrm{C}$. Através do cultivo em lâmina, foi verificada a formação de clamidoconídios após 24,48 e 72 horas de incubação a $37^{0} \mathrm{C}$, visualizados com auxílio de microscópio óptico acoplado à câmara. Nos testes bioquímicos foi verificado reação positiva para fermentação de glicose, com mudança do $\mathrm{pH}$ do meio e produção de gás, bem como, reação negativa para fermentação de sacarose e prova de urease. Os resultados obtidos 
são indicativos que os cinco isolados clínicos pertencem à espécie C.albicans. A relevância de um diagnóstico certeiro, ao nível de espécie é importante para a escolha de um tratamento eficaz e correto, tendo em vista a resistência que esta espécie tem apresentado aos antifúngicos disponíveis no mercado.

Palavras-chave: Identificação de leveduras, Candida albicans, características macro e micro morfológicas.

Apoio financeiro: CNPq, FAPEMIG, CAPES, UFSJ. 